\title{
An Evaluation Of Corporate Sustainability In Context Of The Jevons Paradox
}

\author{
https://doi.org/10.21272/sec.4(3).46-65.2020
}

Marcel Biewendt, ORCID: https://orcid.org/0000-0002-3410-7995

$\mathrm{PhD}$ Candidate in Management \& Organisational Sciences, Kaposvár University, Hungary; Member of Executive Board of IDA Institute at University of Applied Science Aachen, Germany

Florian Blaschke, ORCID: https://orcid.org/0000-0003-2124-2458

PhD Candidate in Management \& Organisational Sciences, Kaposvár University, Hungary; Project Manager, Germany

\section{Arno Böhnert, ORCID: https://orcid.org/0000-0003-2224-6223}

PhD Candidate in Management \& Organisational Sciences, Kaposvár University, Hungary; Sales Director at Robbe \& Berking, Germany

\begin{abstract}
The successful implementation and continuous development of sustainable corporate-level solutions is a challenge. These are endeavours in which social, environmental, and financial aspects must be weighed against each other. They can prove difficult to handle and, in some cases, almost unrealistic. Concepts such as green controlling, IT, and manufacturing look promising and are constantly evolving. This paper aims to achieve a better understanding of the field of corporate sustainability (CS). It will evaluate the hypothesis by which Corporate Sustainability thrives, via being efficient, increasing the performance, and raising the value of the input of the enterprises to the resources used. In fact, Corporate Sustainability on the surface could seem to contradict the idea, which supports the understanding that it encourages the reduction of the heavy reliance on the use of natural resources, the overall environmental impact, and above all, their protection. To understand how the contradictory notion of CS came about, in this part of the paper, the emphasis is placed on providing useful insight to this regard. The first part of this paper summarizes various definitions, organizational theories, and measures used for CS and its derivatives like green controlling, IT, and manufacturing. Second, a case study is given that combines the aforementioned sustainability models. In addition to evaluating the hypothesis, the overarching objective of this paper is to demonstrate the use of green controlling, IT, and manufacturing in the corporate sector. Furthermore, this paper outlines the current challenges and possible directions for CS in the future.
\end{abstract}

Keywords: corporate sustainability, jevons paradox, efficiency side-effects, grey energy, rebound-effect.

JEL Classification: O13.

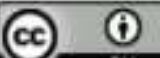

Cite as: Biewendt, M., Blaschke, F., Böhnert, A. (2020). An Evaluation Of Corporate Sustainability In Context Of The Jevons Paradox. SocioEconomic Challenges, 4(3), 46-65. https://doi.org/10.21272/sec.4(3).46-65.2020.

(C) The Authors, 2020. This article is published with open access at Sumy State University.

\section{Introduction}

The subsequent chapter should provide an overview of the relevant research topics that the authors are dealing with. The hypothesis is also duly discussed: Corporate Sustainability thrives on being efficient, increasing the output generated and raising the value of the input of the enterprises to the resources used (Jevons Paradox). The concept of sustainability describes the use of a regenerative system in such a way that the essential properties of the system are preserved and its continuity is maintained by natural regenerative means (Friedag, 2019). Due to the increased demand for sustainable solutions in almost all industries and economies, concepts such as sustainability management or green controlling, IT, and manufacturing offer opportunities to improve 
operations (Hahn \& Scheermesser, 2005). Furthermore, new customers can be reached, and old portfolios can be updated via actions and certifications in the needed area (Schaltegger, Lüdeke-Freund, \& Hansen, 2012).

Some of the inherent advantages are increased brand awareness, consolidation of customer loyalty, image reinforcement, and a surge in business volume. It is equally important to note that the application of sustainable industry solutions will certainly stabilize development and social parameters. This is independent of corporate objectives, as in the case of economic and social development, as in the case of a country. Especially, with regards to developing countries (Baumgartner \& Ebner, 2010). Global impacts such as climate change tend to affect poor countries more as they struggle to mitigate the negative effects of global warming.

This in turns affects the social development and create a tense political atmosphere. It can then be argued that social stability, including other forms of democratic perspectives, is at the mercy of politicians or radical political party policies who offer the so-called "simple" solution to quite complex problems and therefore obstruct the improvement of human development. Being like that, this demand is primarily triggered extrinsically by legal requirements or an adjustment of the company's position to current social trends. Therefore, no trend reversal or reduction in the demand for corporate sustainability is to be expected for the foreseeable future. This is due to the nature of sustainability management. Problems such as environmental pollution, nature conservation, and resource-saving management will remain crucial over the long term to sustain a viable planet for future generations (Vlek \& Steg, 2007).

\section{Material and Methods}

A deductive approach by hypothesis has been used to realise this paper as it seems to fit best in this particular case. Qualitative analysis methods are intended to be used by collecting and analysing secondary data. Secondary data have been collected from relevant literature sources such as journals, reports, books, relevant, and credible newspapers. Furthermore, online research can be used as a data collection method. The data collected has been checked for consistency and reliability by applying a framework that continuously monitors possible biases and errors in the research and hypothesis (Saunders, Lewis, \& Thornhill, 2009). The information gathered should, therefore, allow further research to build on this work. This is supported by a clear, scientific definition of each source used. A qualitative analysis of relevant literature, indices, and theoretical concepts should support or neglect the hypothesis from a different point of view.

Investigating the impact of corporate sustainability has become an increasingly important topic amongst experts in the industry, researchers and some members of the general public. The first efforts to summarise the issues, challenges, and problems of sustainable global development were launched by the United Nations in 1987 with the publication of the so-called "Brundtland Report" under the official title of "Our Common Future" (Nations, 1987). New technologies and a constant change in public awareness, especially with regard to environmental pollution and sustainable solutions have influenced the industry, its processes, and product development (Montiel \& Delgado-Ceballos, 2014). In addition, the global interest of academic researchers in issues of sustainable development and solutions, as well as corporate social responsibility, has increased significantly over the past decades (Swarnapali, 2017). The aim and scope of this study is, therefore, to attempt to provide an overview of the subject matter and demonstrate the application of CS using examples. This will illustrate further the current state and implementation of CS in today's industry.

\section{Aim and Objectives}

This working paper aims to review the relevant and thematic literature in the area of interest, to study the current state of affairs, knowledge of terminology, and conceptual frameworks for the development of green controlling, IT, and manufacturing with a view to possible integration into current industry applications. The focus should also, but not exclusively, be on the following objectives:

$\checkmark$ to give examples of an industry standard for all three sub-areas in a case study,

$\checkmark$ to present the Jevons Paradox in the context of corporate sustainability, and

$\checkmark$ to offer a solution on how to diminish the Jevons paradox.

In order to step into the topic of corporate sustainability, including testing the relevance for potential users, the authors have developed a scientific survey, which has been digitally shared among business professionals using 28 personal interviews for verification of the questionnaire. 
A total of 62 questionnaires were validated and analyzed to highlight the relevance of this topic. By reviewing the results, it can be stated that corporate sustainability is a very relevant topic for business professionals, which unfortunately has not yet been sufficiently considered by many companies. Furthermore, stakeholders seem to have a growing interest in the concept of corporate sustainability, while practical applications are not widely known.

Figure 1 shows that $100 \%$ of the participants considered sustainability to be useful but are unfamiliar with specific terms of the research field as seen in Figure 2. Also, 67.74\% of the participants already deal with sustainability in their day-to-day business.

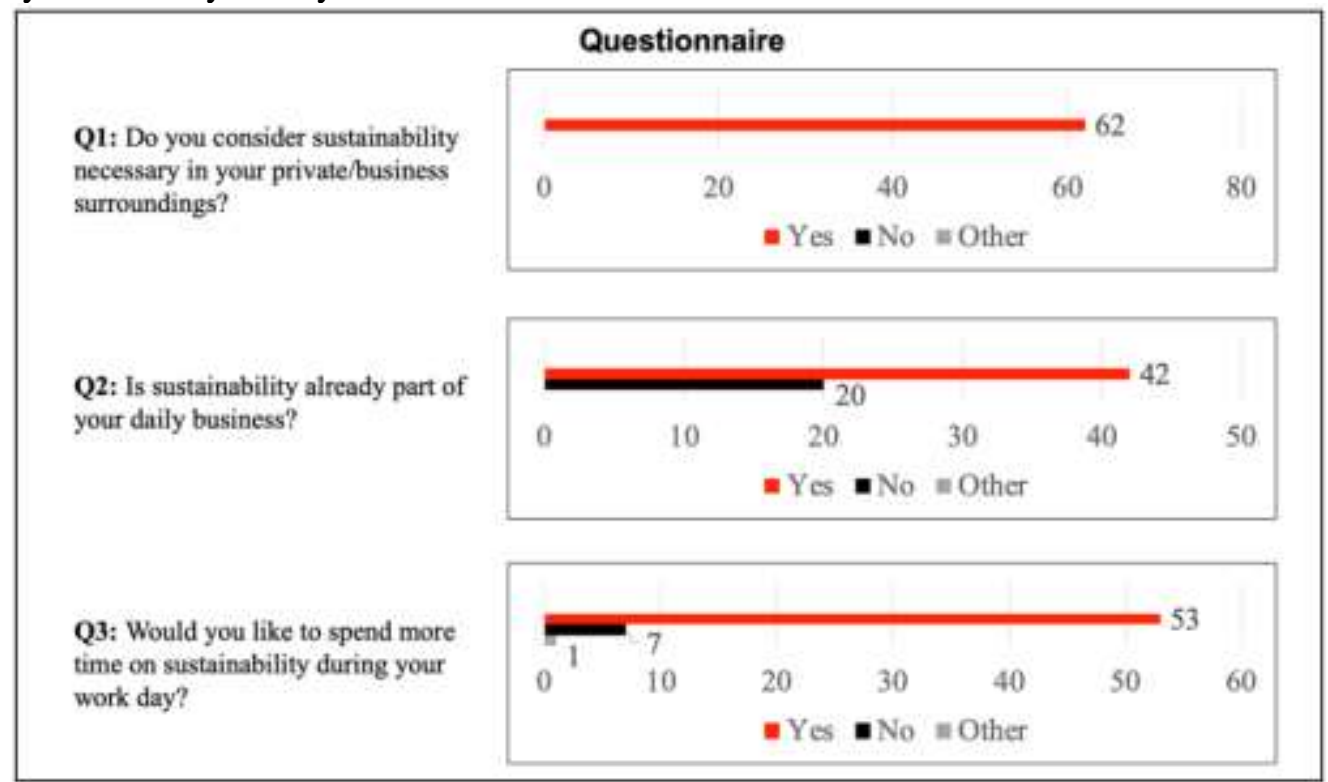

Figure 1. Survey Outcome 1

Source: (Staff, 2019).

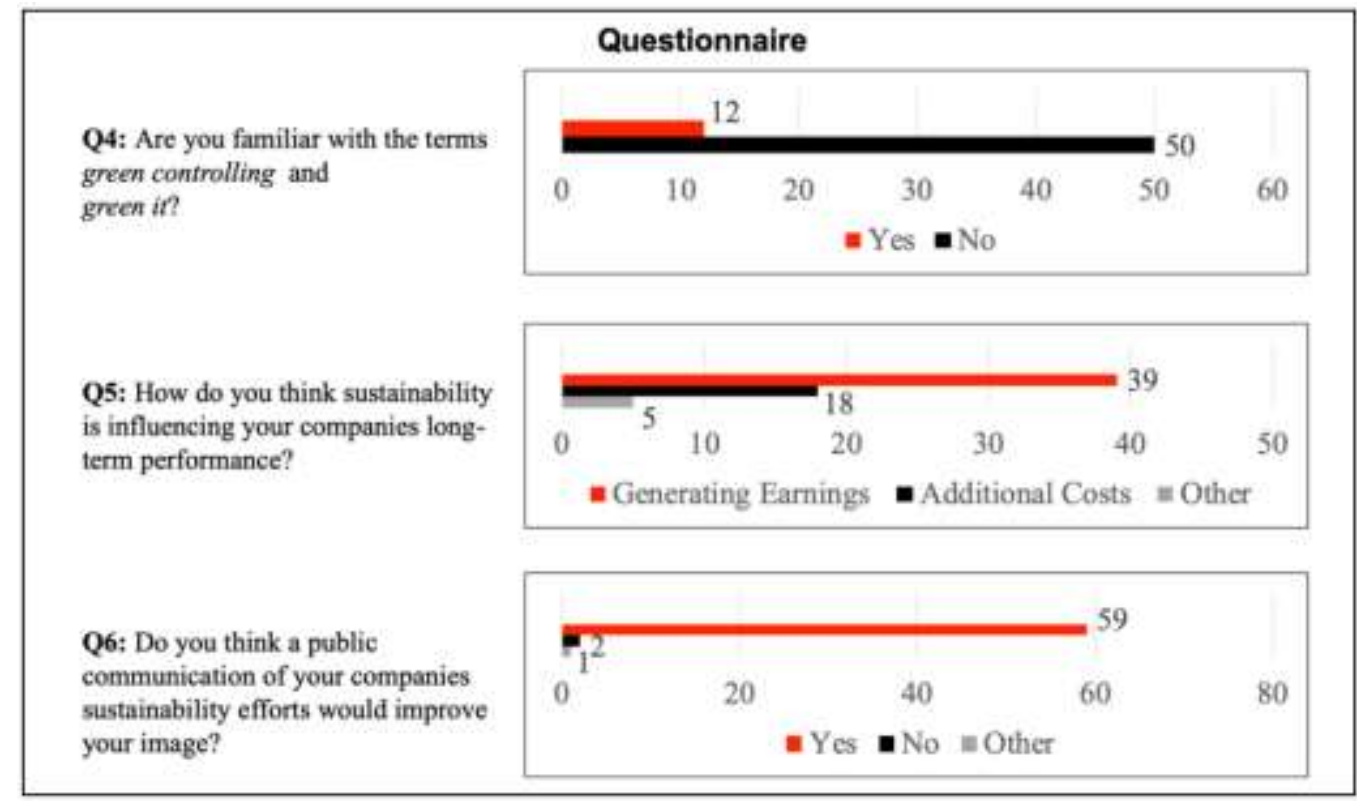

Figure 2. Survey Outcome 2

Source: (Staff, 2019).

In line with these results, Question 3 (Figure 1) with a result of 53 to 7 shows that professionals would like to deal with the topic of sustainability much more frequently and intensively. In contrast, most of the survey 
participants show a lack of specific knowledge in the field of corporate sustainability. Relatively new systems and models like green IT and controlling were unknown to $83.87 \%$ of the participants, which shows that much more information must be delivered and disseminated within the industry. Sustainability as a corporate system is seen first and foremost as an income-generating system (62.90\%), even though $29 \%$ of the participants believe sustainability will cost money rather than generate income. Finally, it should be noted that the term sustainability is readily well accepted. Companies like to present themselves with an expression such as "sustainable" (95.16\%), as this affects the psyche of the general public. The ambitious climate protection and emission reduction targets of most nations will in most cases have an increasing impact on private business sectors as well as governmental projects. This prospect once again underlines the importance of this topic (Dornfeld, Yuan, Diaz, Zhang, \& Vijayaraghavan, 2013).

The chart in Figure 3 "Accumulated publications of Corporate Sustainability" is a representation of the ongoing scientific research in the field of CS by showing the accumulated publications from 2007 until 2019 to demonstrate the relevance of the research field.

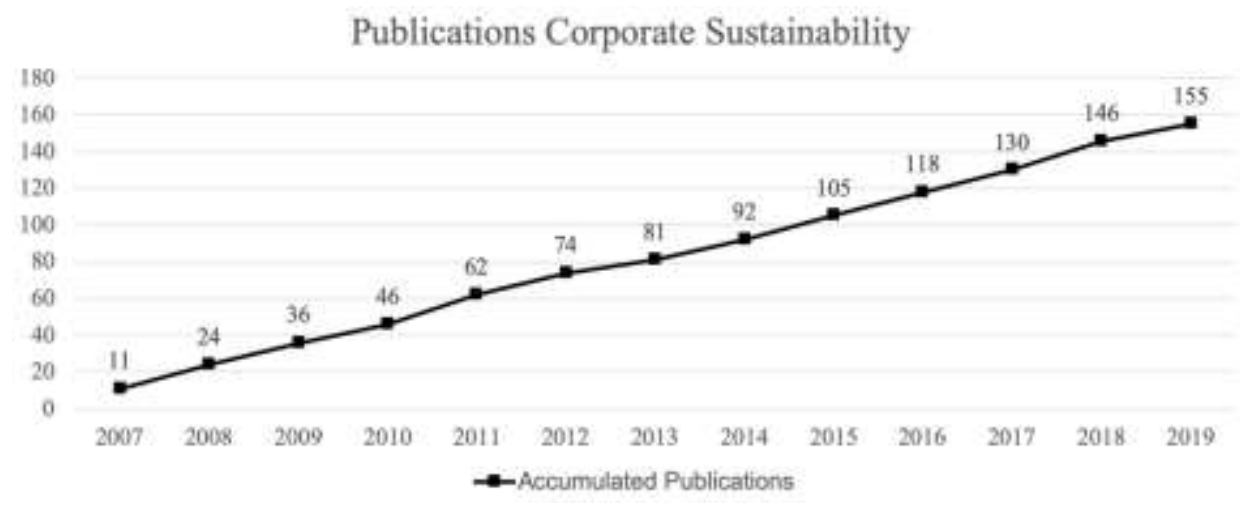

Figure 3. Accumulated publications of Corporate Sustainability

Source: (Scopus, 2019a)

\section{The Jevons Paradox in Context of Corporate Sustainability}

The almost complete dependence on the use of natural resources in industrial production processes has increased remarkably since the Industrial Revolution (Statista, 2019). Despite the most efficient technological advances, the Jevons paradox has the ability to uncover substantial evidence for the argument that mankind must shape its industrial future to protect and preserve the environment in its present state (Jevons (a), 1866; York, Ecological paradoxes: William Stanley Jevons and the paperless office, 2006; Topalli \& Buluş, 2011). This correlation between increased consumption of natural resources and increased efficiency is known as the Jevons Paradox (Agency, 2006; Jevons (a), 1866). The use or consumption of natural resources to provide energy and other consumer goods is often an irreversible process that both reduces the number of resources globally available and increases global environmental pollution (Polimeni \& Iorgulescu, 2006). The deterioration of habitats of various species, a direct consequence of environmental impacts, leads to the rapid extinction of unfortunate species by the use of natural resources (see coal deposits and air quality in Germany between 1950 and 1980) (GermanFederal-Statistical-Office, 2019). The hypothesis that industrial progress will in principle lead to a generally better life for humanity must, therefore, be challenged. Due to global political developments in environmental education, sustainable development, and ecologically sustainable outlook, which are often a subject of conflicting interest, especially due to economic implications, it is strongly recommended to include the Jevons Paradox both socially and scientifically (Global Reporting Initiative, 2019; Hahn \& Scheermesser, 2005; Hopkins, 2004). In order to develop environmentally sound strategies, it is necessary to understand the impacts of economic activities, resource use, and improved efficiency (Polimeni \& Iorgulescu, 2006).

The $20^{\text {th }}$-century theory of "economic growth" sees technological change as the main cause of increased production and consumption (Lewis, 2003). In contrast, some ecologically oriented economists and virtually all governments, green political parties, and NGOs believe that efficiency leads to lower consumption and positive environmental impacts. Others doubt this "efficiency strategy towards sustainability" because they assume that the efficiency gains in pursuing this goal will "decline" or even "backfire", leading to higher 
production and consumption (Dyllick \& Hockerts, 2002; Camilleri M. , 2017; Montiel \& Delgado-Ceballos, 2014). As several environmental problems require rapid and clear policy recommendations, this issue deserves high priority in the environmental economy and political decision-making process. If Jevons is right, efficiency policies are counterproductive. Jevons recommended that efficiency gains must be offset by physical ceilings such as quotas or rationing, which would be in contrast to the liberal economic theories promoted over the last decades (Jevons (b) \& Flux, 1965; Alcott, 2005). Figure 4 shows an example of the Jevons Paradox. It is assumed that the travel cost will fall due to efficiency gains in fuel consumption with elastic demand. This leads to the Jevons Paradox, which accounts for an increase in the number of kilometres travelled by car owners that exceeds the overall savings achieved through increased efficiency improvements. Fuel consumption decreases by $20 \%$, which corresponds to $20 \%$ lower travel costs.

Meanwhile, the number of kilometres travelled increases by $40 \%$, so that in the end, the overall consumption of fuel will rise by $20 \%$. William Stanley Jevons claimed that the technological efficiency gains - especially the "more economical" use of coal in engines which perform mechanical work - actually increased the overall consumption of coal, iron and other resources rather than "reducing" them (Jevons (a), 1866).

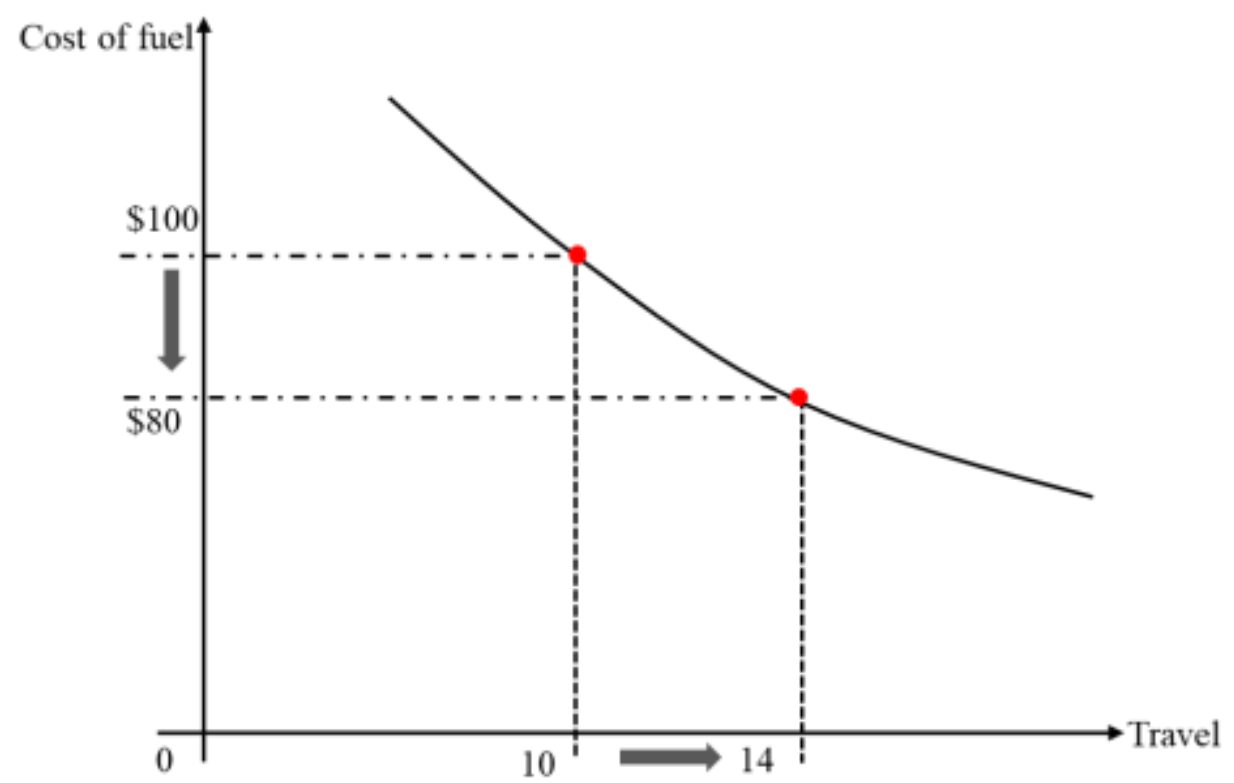

Figure 4. Example of the Jevons Paradox in case of price elasticity of demand

Source: (York \& Mcgee, Understanding the Jevons paradox, 2016; Jevons (a), 1866)

\section{Corporate Sustainability}

Corporate Sustainability is concerned with treating the stakeholders of the company ethically or in a responsible manner. "Ethically or responsible" means treating stakeholders in a way that is considered acceptable in civilized societies, including economic responsibility (Camilleri M. , 2017). Stakeholders exist both within and outside a company. The natural environment is a stakeholder. The wider aim of social responsibility is to create a high standard of living while maintaining the profitability of the company for people both within and outside the company (Hopkins, 2004). There are several ways to define sustainable development, but the most frequently quoted is the Brundtland Report 1987 known as "Our Common Future" (Brundtland, 2019). The central contribution of this report is to link human development and actions with environmental responsibility (Camilleri M. , 2013).

Businesses and governments are changing their position on sustainability and focusing on sustainable principles and regulatory guidelines (e.g. Global Reporting Initiative's Sustainability Reporting Guidelines, UN Global Compact and the Sustainable Development Goals, etc.) (Global Reporting Initiative, 2019; UN Global Compact, 2019). Companies are therefore redesigning their standards, corporate programs, codes of conduct, and green policies (Brundtland, 2019). Corporate sustainability is also linked to economic, social, and ecological systems, which are all interrelated (Camilleri M. , 2017). Dyllick and Hockerts define ecoefficiency, socio-efficiency, eco-effectiveness, socio-effectiveness and sufficiency, and ecological equity as 
core criteria for corporate sustainability (Dyllick \& Hockerts, 2002). Altogether, 144 journals and 11 conference papers have been selected for this analysis. This literature review focuses on the database Scopus (Scopus, 2019a) and excludes a small number of corporate sustainability publications before 2000. Using the database Scopus and omitting these papers does not mean that there is no multidisciplinary view of corporate sustainability. The scientific work is presented through a large number of papers to minimize distortion. The inclusion of a small number of related papers published before 2007 would not have changed the overview of corporate sustainability literature. Table 1 demonstrates the constant interest in corporate sustainability from 2007 to 2019.

The analysis of the 155 papers (Scopus, 2019a) has shown that corporate sustainability definitions differ across the same discipline. "The social responsibility of business is to increase its profit only to the extent that it contributes to the aim of business, which is the creation of long-term value for the owners of the business" (Friedman, Foley, \& Marrewijk, 2003). Marrewijk and Were link "Corporate Sustainability, and also CSR, refers to a company's activities voluntary by definition - demonstrating the inclusion of social and environmental concerns in business operations and in interactions with stakeholders." (Marrewijk \& Werre, 2003). Schrave mentions that "there is no standard recipe: corporate sustainability is a custom-made process" (Schrave, 2003). Further definitions of corporate sustainability in literature can be found in articles by (Dyllick \& Hockerts, 2002; Hopkins, 2004; Camilleri M. , 2013). In summary, one could say that the majority generally agree that "Corporate sustainability creates higher and higher standards of living while preserving the profitability of the corporation, for peoples both within and outside the corporation" (Hopkins, 2004).

Table 1. Dissemination of Corporate Sustainability

\begin{tabular}{|c|c|c|c|}
\hline Year & Number of journal-papers & Number of conference papers & Total \\
\hline 2007 & 10 & 1 & 11 \\
\hline 2008 & 12 & 1 & 13 \\
\hline 2009 & 11 & 1 & 10 \\
\hline 2010 & 8 & 2 & 16 \\
\hline 2011 & 15 & 1 & 12 \\
\hline 2012 & 9 & 3 & 7 \\
\hline 2013 & 5 & 2 & 11 \\
\hline 2014 & 11 & - & 13 \\
\hline 2015 & 13 & - & 13 \\
\hline 2016 & 13 & - & 12 \\
\hline 2017 & 12 & - & 16 \\
\hline 2018 & 16 & - & 9 \\
\hline 2019 & 9 & - & 155 \\
\hline Total & 144 & 11 & \\
\hline
\end{tabular}

Source: (Scopus, 2019a).

\section{Review of Green IT}

Murugesan mentioned that "Green IT includes the dimensions of environmental sustainability, the economics of energy efficiency, and the total cost of ownership, which includes the cost of disposal and recycling" (Murugesan, 2008). According to that, Green IT comprises a number of areas and activities.

$>$ Design for environmental sustainability,

$>$ Energy-efficient computing,

$>$ Responsible disposal and recycling,

$>$ Green metrics, assessment tools and methodology,

$>$ Environment-related risk mitigation, and

$>$ Use of renewable energy sources.

Green IT uses IT equipment that is energy-efficient and reduces energy consumption for the operation of information technologies (Schmermbeck, 2019). Brooks et al. found that the term Green IT appeared in CIO magazine in 2007 (Brooks, Wang, \& Sarker, 2010, S. 3).. Starting from 2007, Elliot, Etzion, Feng and Cameron and Vlek and Steg mentioned Green IT (Elliot, 2007; Etzion, 2007; Feng \& Cameron, 2007; Vlek \& Steg, 2007). For this reason, the analysis of this paper begins from January 2007 and finishes in April 2019. Altogether, 181 journals and 121 conference papers have been selected for the analysis. This literature review 
focuses on the database Scopus (Scopus, 2019b) and excludes a small number of Green IT publications prior to 2000. Using the database Scopus and omitting these papers does not mean that there is no multidisciplinary view of Green IT. Therefore, the leading IT and management journals and conference papers were selected by searching for papers containing the term 'Green IT'. The scientific work is giving a large number of papers to minimize distortion. Furthermore, most of the literature was written after the coining of the term Green IT in 2007. The inclusion of a small number of related papers published before 2007 would not have changed the overview of Green IT literature. The analysis of the 302 papers (Scopus, 2019b) in Table 2 has shown that the definitions of Green IT differ across the same discipline.

Table 2. Dissemination of Green IT Publications

\begin{tabular}{|c|c|c|c|}
\hline Year & Number of journal-papers & Number of conference papers & Total \\
\hline 2007 & 3 & 1 & 4 \\
\hline 2008 & 7 & 2 & 27 \\
\hline 2009 & 9 & 16 & 32 \\
\hline 2010 & 12 & 20 & 37 \\
\hline 2011 & 21 & 16 & 37 \\
\hline 2012 & 19 & 18 & 30 \\
\hline 2013 & 14 & 16 & 30 \\
\hline 2014 & 15 & 15 & 30 \\
\hline 2015 & 22 & 8 & 10 \\
\hline 2016 & 8 & 2 & 27 \\
\hline 2018 & 23 & 4 & 21 \\
\hline 2019 & 18 & 3 & 10 \\
\hline Total & 10 & 0 & 302 \\
\hline
\end{tabular}

Source: (Scopus, 2019b).

Erek et al. defined "Green IT [as] the systematic application of practices that enable the minimization of the environmental impact of IT, maximize efficiency and allow for company-wide emission reductions based on technology innovations" (Erek, Loeser, Schmidt, \& Zarnekow, 2011). There are a number of definitions of Green IT in the literature (Elliot, 2007; Sayeed \& Gill, 2009; Molla, Cooper, \& Pittayachawan, 2009; Erek, Loeser, Schmidt, \& Zarnekow, 2011). In this paper, Green IT refers to the use of IT equipment that is energyefficient in order to reduce the energy consumption for IT operations (Schmermbeck, 2019).

Further, Sayeed and Gill identified that "Green IT initiatives are organizational activities that aim to engender environmentally sustainable consequences in the conduct of information processing tasks of an enterprise" (Sayeed \& Gill, 2009). Molla et al. describe "Green IT [as] an organization's ability to systematically apply environmental sustainability criteria (such as pollution prevention, $[\ldots]$ use of clean technologies) to the design, production, sourcing, use and disposal of the IT technical [...]" (Molla, Cooper, \& Pittayachawan, 2009).

\section{Review of Green Controlling}

Green controlling is a form of controlling that supports sustainable corporate development. Green controlling extends the economic part of the pilot function in controlling beyond the ecological aspect. In addition to classic controlling, green controlling should refer to the following aspects (Friedag, 2019):

Economic: Provide a sustainable basis for acquisition and prosperity in the long term.

Ecological: Nature and environment should be preserved for future generations.

Social: A society that is worth living in the long run must be achieved.

Cultural: The culture in which people live in their everyday lives must be aligned with the guiding principle of sustainability.

Table 3 focuses on the Scopus database (Scopus, 2019c; Scopus, 2019d) and excludes a small number of Green Controlling publications prior to 2000. The concept and terminology "Green Controlling" (GC) started to appear in Germany in the early 2000s, and the definitions and implementations have continued to develop ever since. As seen in Table 3, there are only very few publications in journals on the subject of Green Controlling. This shows that Green Controlling has not yet obtained the necessary awareness and interest in the field of academic research. So far, most of the authors who have been writing about Green Controlling refer to (Tschandl \& Posch, 2003; International Controller Verein eV, 2011). 
Table 3. Dissemination of Green Controlling publications

\begin{tabular}{|c|c|c|c|}
\hline Year & Number of journal-papers & Number of conference papers & Total \\
\hline 2007 & - & - & - \\
\hline 2008 & - & - & - \\
\hline 2009 & - & - & - \\
\hline 2010 & - & - & - \\
\hline 2011 & - & - & - \\
\hline 2012 & - & - & - \\
\hline 2013 & - & - & - \\
\hline 2014 & - & - & - \\
\hline 2015 & 1 & - & - \\
\hline 2016 & - & - & - \\
\hline 2017 & 1 & - & - \\
\hline 2018 & 1 & - & 6 \\
\hline 2019 & 3 & - & - \\
\hline
\end{tabular}

Source: (Scopus, 2019c; Scopus, 2019d).

Controllers play an active role in supporting the green transformation of their company, which is not only limited to the proof of economic efficiency or the collection of key figures but also includes the sensitization, consulting, and motivation of management and other actors by constantly questioning ecological and economic interrelationships (International Controller Verein eV, 2011). With regard to the perception of the tasks of Green Controlling, the majority of those surveyed in the study published in 2011 by the "International Controller Association e.V.", assume that green aspects will be integrated into corporate controlling. A separate and isolated Green Controlling by the actors of environmental management is thereby to be avoided. If the strategic importance of greening is low, this position is less clear. The controlling tasks resulting from the increasing strategic importance of greening are not fundamentally new controlling tasks, but rather an extension of the core tasks of controlling to new green goals and information (International Controller Verein eV, 2011; Friedag, 2019). For companies, this results in the task of adapting their existing controlling instruments accordingly and setting up a so-called "Green Controlling Toolbox". Within the framework of strategic planning, instruments such as stakeholder analyses, portfolio techniques for market potential analysis, scenario techniques, or a Sustainability Balanced Scorecard (SBSC) are conceivable. In cost, performance, profit and loss accounting, for example, the task is to map environmental costs in the context of environmental cost accounting. In project and investment controlling, for example, ecological considerations can increasingly be integrated into lifecycle assessments or green target costing (Haufe, 2019; Friedag, 2019; International Controller Verein eV, 2011).

\section{Review of Green Manufacturing}

This review focuses on the Scopus database (Scopus, 2019e) and excludes a small number of Green Manufacturing publications prior to 2000 (Table 4).

Table 4. Dissemination of Green Manufacturing Publications

\begin{tabular}{|c|c|c|c|}
\hline Year & Number of journal-papers & Number of conference papers & Total \\
\hline 2007 & 10 & 4 & 14 \\
\hline 2008 & 9 & 2 & 15 \\
\hline 2009 & 7 & 14 & 28 \\
\hline 2010 & 14 & 9 & 30 \\
\hline 2011 & 17 & 5 & 46 \\
\hline 2012 & 25 & 7 & 32 \\
\hline 2013 & 39 & 1 & 28 \\
\hline 2014 & 31 & 3 & 29 \\
\hline 2015 & 25 & 4 & 25 \\
\hline 2016 & 25 & 5 & 36 \\
\hline 2017 & 20 & 5 & 5 \\
\hline 2018 & 31 & 1 & 325 \\
\hline 2019 & 4 & 68 & \\
\hline Total & 257 & & \\
\hline
\end{tabular}

Source: (Scopus, 2019e). 
The presented Table 4 shows an increasing interest in the field of green manufacturing from 2010, which has existed ever since. The concept and terminology "Green Manufacturing" first appeared in Germany in the late 1980s and since then has evolved technology-wise as well as in meaning and understanding. Until now, no mutually exclusive definition has been adopted in the literature (Rehman \& Shrivastava, 2013). Therefore, it is necessary to look at the topic from different perspectives and sort out a common understanding for this paper. Our review of GM is part of the wider field of corporate social responsibility.

From a linguistic point of view, "green" and "manufacturing" can be separated. In the context of corporate social responsibility, "green" stands for ecological sustainability and encompasses several different concerns including, but not limited to, water, air and soil pollution, energy consumption, and waste generation and recycling. For the context of this work, "green" may be summarised as follows: "Concerned with or supporting environmentalism and tending to preserve environmental quality" (Dornfeld, Yuan, Diaz, Zhang, \& Vijayaraghavan, 2013; Bhattacharya, Jain, \& Choudhary, 2011; Deif, 2011).

Manufacturing is a series of processes that include: the selection of raw materials, production or manufacture of an object or objects, building or constructing, assembling the parts, inspection or examination, and finally dispatching. The overarching goal of Green Manufacturing (GM) is the reduction and conservation of resources by designing the manufacturing process for minimal or non-existent negative impact on the environment (Sri Darapu \& Satish Kumar Darapu, 2014; Dornfeld, Yuan, Diaz, Zhang, \& Vijayaraghavan, 2013). Another key element is the product design itself, which should focus on recyclable and reusable materials (Verma, Dixit, \& Singh, 2018, S. 44). Furthermore, GM also includes socially responsible manufacturing that focuses on employee safety precautions and risk protection for humans and nature (Niehoff, Chenlung, Litzang, \& Chwen, 2011). If the greening ambition is including the multidimensional procedure of supply and distribution, the literature refers to Green Supply Chain Management (GSCM) (Verma, Dixit, \& Singh, 2018).

Two key figures to measure the environmental impact of a factory are the virtual water and grey energy consumption. Virtual water was introduced by Allan in 1993 and calculates the amount of water required for the entire production process of one product (Lillywhite, 2010). This calculation includes neglected and hidden components of water consumption from start to finish (Singh, Boland, \& Thompson, 2014). Similar to virtual water, grey energy combines the entire energy consumption necessary to manufacture a product throughout its whole production process. The term grey indicates that not all the energy-consuming parts are known (Pao \& Tsai, 2011). In both cases, it is nearly impossible to derive an exhaustive precise number because of the complexity of manufacturing and the supply chains involved. Nonetheless, both figures are of great importance to review the ecological impact of a product and its predicted resource consumption (Pao, $\mathrm{Fu}, \&$ Tseng, Energy, 2012).

\section{Case Study - Corporate Sustainability in an Industrial Context}

Environmental sustainability measures such as the reduction of Carbon Dioxide (CO2), grey energy, and virtual water conservation in the automotive industry create unfavourable conditions for production costs, and inventories are essential to reduce the ecological footprint (Abduaziz, Kie Cheng, Mat Tahar, \& Varma, 2015).

This transformation can only be achieved by rapidly reducing the resource- and energy intensity in the manufacturing of existing goods by investigating the options for a thorough redesign of the industrial system and by radically rethinking business models (Tonelli, Taticchi, \& Evans, 2013). The following case study is based on three real-world examples that have been anonymised, summarised into one use case, and placed in the context of the Jevons Paradox. The authors decided to process the following three sub-genres of Corporate Sustainability (Schrader \& Vollmar, 2013):

a) Green Controlling;

b) Green IT;

c) Green Manufacturing.

The case study aims to demonstrate both the current possibilities for applied corporate sustainability and its side effects regarding the Jevons Paradox. Particularly hard-hit countries are high-tech ones, such as Japan, the USA, or Germany, which tend to replace workers with machines, as productivity gains are often achieved by efficiency gains through automation and digitization (Abolhassan \& Kellermann, 2016). It is therefore 
intended to combine scientific research with today's industrial reality to visualize how e.g. economies need to adjust and politicians need to take previously unrecognized side effects into account when planning efficiency strategies.

\section{$B^{3}$ Engineering Systems - Applied Science}

$\mathrm{B}^{3}$ Engineering Systems is a medium-sized company based in Southern Germany. The company is a manufacturer of innovative electric buses and currently employs around 2,000 people. $\mathrm{B}^{3}$ Engineering Systems currently operates mainly in the national markets of DACH (Germany, Austria and Switzerland). In its strategic plan S2020, the company management aims to increase productivity through gains in efficiency. Since classical measures have not had the desired effect yet, the new Corporate Sustainability department is being set up on behalf of the company management. B $^{3}$ Engineering Systems will introduce CS at the beginning of the fiscal year and would like to have a company analysis carried out in advance by the newly established department in order to uncover optimization potential with regard to productivity and efficiency increases. It is important for the management that this increase in productivity is not at the expense of the environment. The aim is, therefore, to make existing processes more sustainable or, if applicable, to create new processes that are profitable from both an entrepreneurial and an ecological point of view. The Corporate Sustainability department consists of the subdivisions of Green Controlling, Green IT, and Green Manufacturing. The sub-divisions work together to develop a company-wide concept (Figure 5).

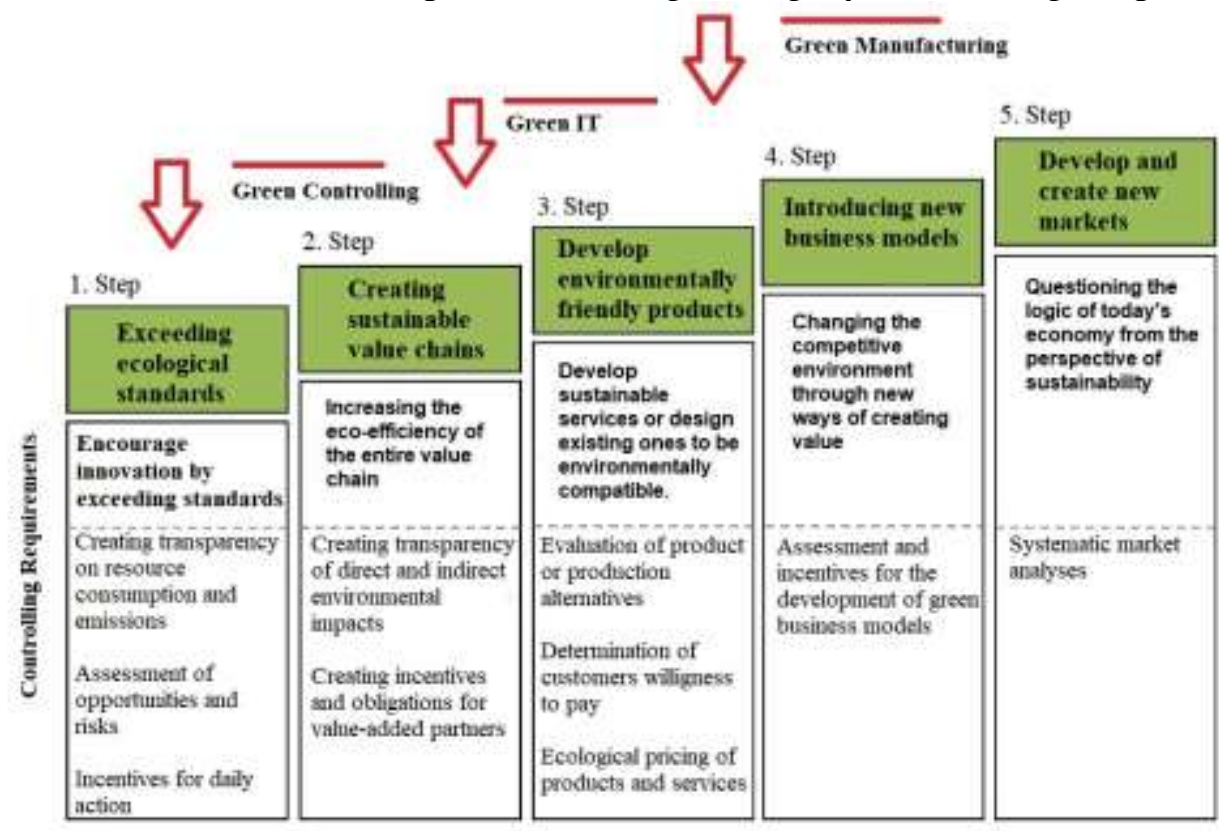

Figure 5. Strategy Plan of the Department of Corporate Sustainability

Source: graphic was derived and modified from (International Controller Verein eV, 2011; Schrader \& Vollmar, 2013).

\section{Green Controlling}

The aim of the GC subdivision is to set goals, plan, and manage ecological sustainability, which can be implemented downstream by the Green IT and Green Manufacturing subdivisions. From the point of view of Green Controlling, a key figure analysis must first be carried out, followed by the creation of an action plan, which will be executed by the Green IT and Green Manufacturing subdivisions. The GC department, therefore, creates Sustainability Balanced Scorecards as seen in Table 5 \& Table 6.

Table 5. B ${ }^{3}$ Engineering Systems - Sustainability Balanced Scorecard - Financial Perspective

\begin{tabular}{|c|c|c|}
\hline Strategic Goal & Measured Values & Target Values \\
\hline Increase Profitability & $6 \%$ & $7 \%$ \\
\hline Increase Liquidity & $118 \%$ & $120 \%$ \\
\hline Decrease Environmental-Costs & $0.05 € /$ working hour & $0.03 € /$ working hour \\
\hline
\end{tabular}

Notes: *Environmental-Costs include environmental relevant costs like waste, energy consumption, freshwater usage and Co2 emissions.

Source: modified and derived from (Schrader \& Vollmar, 2013). 
Table 6. B ${ }^{3}$ Engineering Systems - Sustainability Balanced Scorecard- Environmental Perspective

\begin{tabular}{|c|c|c|}
\hline Strategic Goal & Measured Values & Target Values \\
\hline Decrease Grey Energy Usage & $50,000 \mathrm{kWh}$ & $40,000 \mathrm{kWh}$ \\
\hline Decrease Co2 Emissions & 15 tons & 12 tons \\
\hline Decrease Virtual Water & 300,000 litres & 240,000 litres \\
\hline
\end{tabular}

Notes: *Grey Energy: the amount of energy required to manufacture, transport, store, sell and dispose a product;

Virtual Water: refers to the quantity of water actually used for the manufacture of a product.

Source: modified and derived from (Schrader \& Vollmar, 2013).

\section{Green IT}

$\mathrm{B}^{3}$ Engineering Systems uses Green IT technologies for processing simulation, validation, and verification techniques based on digital models. The following example from the $\mathrm{B}^{3}$ Engineering System shows the quantitative effects of Green IT in the product development process. Figure 6 shows much higher resource consumption for Green IT (Y1 Peak usage GI \& X1 peak GI) compared to conventional development (Y0 Peak usage $\mathrm{CD} \& \mathrm{X} 0$ peak $\mathrm{CD}$ ). However, if you compare CD (Y2 usage CD \& X2 cost) and GI (Y3 usage GI \& X3 cost), the cost over the entire product development process for the $\mathrm{CD}$ is higher because late changes are costlier than at an earlier point in time. Therefore, higher resource consumption is compensated by the lower cost of GI throughout the entire product development process. The biggest advantage of using GI technologies is the former final maturity of the series (X5 final series maturity GI vs. X4 final series maturity CD).

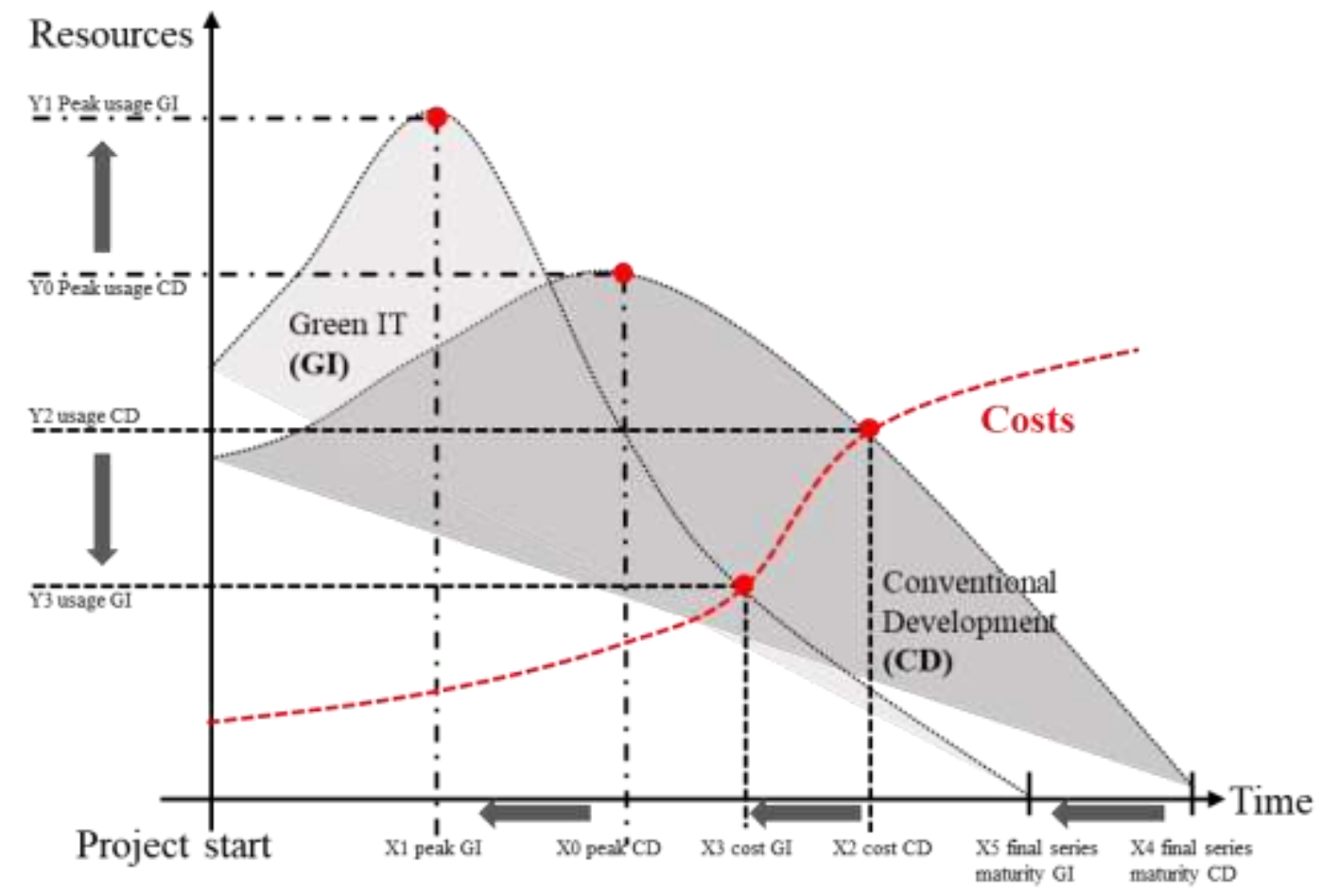

Figure 6. Added value of virtual engineering

Source: modified and derived from (Eigner \& Stelzer, 2009).

The controlling department of $\mathrm{B}^{3}$ Engineering Systems therefore listed a number of more or less concrete or quantifiable data. The data collected from the controlling department allowed $\mathrm{B}^{3}$ Engineering Systems to identify the benefits by applying a virtual simulation. The controlling numbers are based on simulation test reports, physical test reports, and simulation methodologies. To simplify the model, all data values from Figure 6 are normally distributed and differently proportioned. For the calculation in Table 7, test procedures were applied, in which one bus is used. The basis for calculation is the numbers of the controlling department: 10,000 kilowatt hours of grey energy, 3,000 kilograms of carbon dioxide, and 60,000 litres. 
Table 7. Physical prototype and simulation comparison

\begin{tabular}{|c|c|c|c|c|c|c|c|c|}
\hline Test & $\begin{array}{c}\text { Physical } \\
\text { prototype } \\
\%\end{array}$ & Grey energy & $\begin{array}{l}\text { Carbon dioxide } \\
\qquad\left(\mathrm{CO}_{2}\right)\end{array}$ & $\begin{array}{l}\text { Virtual } \\
\text { water }\end{array}$ & $\begin{array}{c}\text { Virtual } \\
\text { simulation } \\
\%\end{array}$ & $\begin{array}{c}\text { Grey } \\
\text { energy }\end{array}$ & $\begin{array}{c}\text { Carbon } \\
\text { dioxide } \\
\left(\mathrm{CO}_{2}\right)\end{array}$ & $\begin{array}{l}\text { Virtual } \\
\text { water }\end{array}$ \\
\hline Body temperature & $40 \%$ & $4,000 \mathrm{kWh}$ & $1,200 \mathrm{~kg}$ & $24,000 \mathrm{I}$ & $20 \%$ & $2,000 \mathrm{kWh}$ & $600 \mathrm{~kg}$ & $12,000 \mathrm{I}$ \\
\hline Roof crush & $90 \%$ & $9,000 \mathrm{kWh}$ & $2,700 \mathrm{~kg}$ & 54,0001 & $50 \%$ & $5,000 \mathrm{kWh}$ & $1,500 \mathrm{~kg}$ & 30,0001 \\
\hline Side crash & $100 \%$ & $10,000 \mathrm{kWh}$ & $3,000 \mathrm{~kg}$ & 60,0001 & $60 \%$ & $6,000 \mathrm{kWh}$ & $1,800 \mathrm{~kg}$ & 36,0001 \\
\hline \multicolumn{2}{|c|}{ Total } & $23,000 \mathrm{kWh}$ & $6,900 \mathrm{~kg}$ & 138,0001 & & $13,000 \mathrm{kWh}$ & $3,900 \mathrm{~kg}$ & 78,0001 \\
\hline \multicolumn{2}{|c|}{ Resource Savings } & - & - & - & & $10,000 \mathrm{kWh}$ & $3,000 \mathrm{~kg}$ & 60,0001 \\
\hline
\end{tabular}

Source: modified and derived from (Chan, 2003).

As a result, all four tests have the potential to reduce one physical prototype, with $10,000 \mathrm{kWh}$ grey energy, 3,000 kg carbon dioxide (CO2) and 60,000 litres virtual water using virtual engineering. Consequently, the virtual simulation test does not eliminate the physical prototype due to legal requirements, limitations of simulation methods, or correlations with physical prototypes. Using Figure 7 for the interpretation of the calculated values in Table 7, it can be seen that the resource consumption initially increases through the use of virtual engineering technologies. Nevertheless, virtual engineering technologies save $35 \%$ (Figure 7) of the whole product development time but provide a higher level of maturity of competence at an earlier stage of the product development process. This is because virtual engineering technologies can be redone as often as needed with stable costs, whereas physical prototypes are very much time and resource consuming as well as very costly in later stages of their product development.

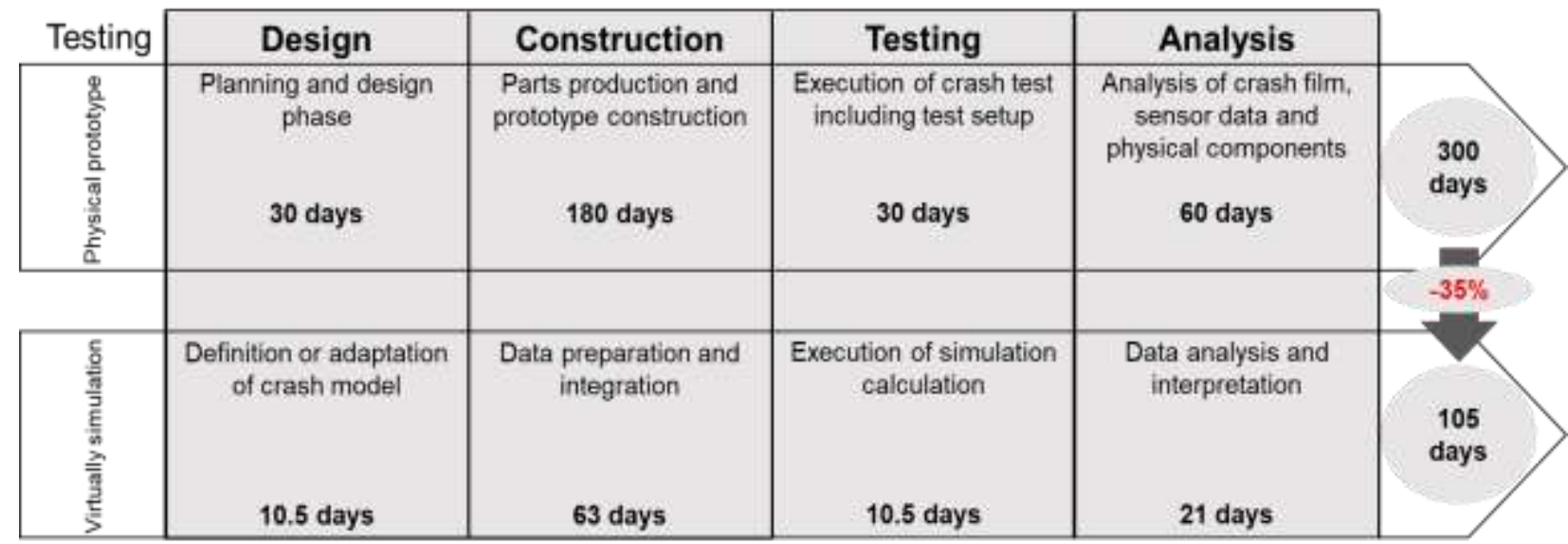

Figure 7. Product development testing time

Source: modified and derived from (Westkämper, Spath, Constantinescu, \& Lentes, 2013).

\section{Green Manufacturing}

As new resources have been released through the implementation of Green IT systems, the Green Manufacturing subdivision can leverage these resources to work towards implementing a sustainable manufacturing program based on strategic corporate sustainability goals: to gradually develop and construct a minibus that uses recycled plastic parts and which is therefore believed to have a better ecological footprint. Research needs to be carried out, and the interior components manufacturing facility needs to be updated. The interior of the minibus is currently manufactured of one-way, disposable plastic. By using the new digital Green IT-based design and test facilities, it is possible to develop and simultaneously test new recyclable materials without wasting capital goods. Due to the $35 \%$ more effective testing department, it is possible to reallocate research resources. Testing shows that $80 \%$ of the interior can be manufactured using recycled materials. In order to integrate new materials, it is necessary to reconstruct the interior manufacturing process. The combined repercussions on the environmental footprint can be seen in Table 8 . 
Table 8. Environmental impact of Green IT \& Green Manufacturing

\begin{tabular}{|c|c|c|c|c|c|c|c|}
\hline \multicolumn{3}{|c|}{ Virtual Water } & \multicolumn{2}{|c|}{ CO2 Emissions } & \multicolumn{3}{|c|}{ Grey Energy } \\
\hline \multicolumn{2}{|c|}{ GI Savings } & 3.000 .0001 & GI Savings & $100 \mathrm{t} / \mathrm{CO} 2$ & \multicolumn{2}{|l|}{ GI Savings } & $500.000 \mathrm{kWh}$ \\
\hline \multirow{4}{*}{ 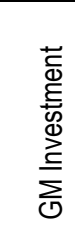 } & $R \& D$ & -200.0001 & GM Investment & $-85 \mathrm{t} / \mathrm{CO} 2$ & \multirow{4}{*}{ 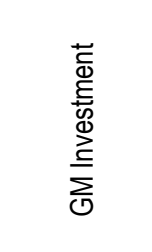 } & $R \& D$ & $\begin{array}{l}-110.000 \\
k W h\end{array}$ \\
\hline & Manufacturing & $-1.400 .000 I$ & After Investing = & $15 \mathrm{t} / \mathrm{CO} 2$ & & Manufacturing & $\begin{array}{l}-175.000 \\
k W h\end{array}$ \\
\hline & Transportation & -750.0001 & GM Savings & $+75 \mathrm{t} / \mathrm{CO} 2$ & & Transportation & $-65.000 \mathrm{kWh}$ \\
\hline & Setup & -250.000 I & Total $=$ & 90 t/CO2 & & Setup & $-50.000 \mathrm{kWh}$ \\
\hline \multicolumn{2}{|c|}{ After Investing = } & 400.0001 & & & \multicolumn{2}{|c|}{ After Investing = } & $100.000 \mathrm{kWh}$ \\
\hline \multicolumn{2}{|c|}{ GM Savings } & +1.050 .0001 & & & \multicolumn{2}{|l|}{ GM Savings } & $190.000 \mathrm{kWh}$ \\
\hline \multicolumn{2}{|c|}{ Total $=$} & 1.450 .0001 & & & \multicolumn{2}{|l|}{ Total $=$} & $290.000 \mathrm{kWh}$ \\
\hline & \multicolumn{5}{|c|}{ Green Manufacturing savings per Minibus } & Total $(50)$ & \\
\hline & One-Way Plastic & $1400 \mathrm{~kg}$ & Recycled Plastic & $1400 \mathrm{~kg}$ & Savings & Total Savings & \\
\hline & $\begin{array}{l}\text { Grey Energy } \\
17 \text { kWh/kg }\end{array}$ & $23.800 \mathrm{kWh}$ & $\begin{array}{l}\text { Grey Energy } \\
10 \mathrm{kWh} / \mathrm{kg}\end{array}$ & $20.000 \mathrm{kWh}$ & $3.800 \mathrm{kWh}$ & $190.000 \mathrm{kWh}$ & \\
\hline & $\begin{array}{l}\text { Carbon Dioxide } \\
10,71 \mathrm{CO} / \mathrm{kg} \\
\end{array}$ & $15 t$ & $\begin{array}{lr}\text { Carbon } & \text { Dioxide } \\
(\mathrm{CO} 2) & 9,64 \\
\mathrm{CO} 2 / \mathrm{kg} & \\
\end{array}$ & $13,5 \mathrm{t}$ & $0,3 \mathrm{t}$ & $15 t$ & \\
\hline & $\begin{array}{l}\text { Virtua I Water } \\
215 \text { I pro kg }\end{array}$ & 301.0001 & $\begin{array}{l}\text { Virtual Water } \\
205 \text { Liter pro kg }\end{array}$ & 287.000 Liter & $14.000 I$ & 700.0001 & \\
\hline
\end{tabular}

Source: modified and derived from (Chan, 2003).

The implementation of GI has saved resources that have now been partially consumed again by investing in GM. In particular, $87 \%$ of the virtual water saved was reinvested, but the new technology used from now on saves an additional 23,800 litres per bus, which is a total savings of 1,050,000 litres for 50 buses. In addition, $85 \%$ of $\mathrm{CO}_{2}$ emissions saved by GI have been reinvested, leading to a decrease of 1.5 tonnes of $\mathrm{CO}_{2}$ per bus and overall GM savings of 75 tonnes of $\mathrm{CO}_{2}$ saved on the whole production. Grey energy has been reduced by $500,000 \mathrm{kWh}$, of which $84 \%$ was reinvested in GM. This led to a reduction in the manufacturing-based grey energy consumption of 3,800 kWh per bus and 190,000 kWh for 50 buses. Both measures combined result in a positive environmental saving of 1,450,000 litres of virtual water, 90 tonnes/ $\mathrm{CO}_{2}$ and $290,000 \mathrm{kWh}$ if 50 buses are produced. To measure the monetary impact of using recycled plastic parts, a cost analysis is needed, as shown in Table 9.

Table 9. Cost Structure Minibus

\begin{tabular}{|c|c|c|c|c|c|}
\hline \multicolumn{2}{|c|}{ Old Cost Structure } & \multicolumn{2}{|c|}{ Cost } & \multicolumn{2}{|c|}{ New Cost Structure } \\
\hline List Price incl. VAT & $150.000,00 €$ & Engine & & List Price incl. VAT & $140.000,00 €$ \\
\hline - VAT (19\%) & $23.949,58 €$ & $-30 \%$ & & - VAT (19\%) & $22.352,94 €$ \\
\hline List Price Net & $126.050,42 €$ & Exterior & & List Price Net & $117.647,06 €$ \\
\hline - Distribution $(14,7 \%)$ & $18.534,08 €$ & $-20 \%$ & & $\begin{array}{ll} & \text { Distribution } \\
(15,75 \%) & \end{array}$ & $18.534,08 €$ \\
\hline - Labour $(10,37 \%)$ & $13.071,90 €$ & Interior $=$ & Non-Recyclable & - Labour $(11,11 \%)$ & $13.071,90 €$ \\
\hline - Material $(32,70 \%)$ & $41.223,15 €$ & $-40 \%$ & $-40 \%$ & - Material $(24,33 \%)$ & $28.618,11 €$ \\
\hline - Depreciation $(6,7 \%)$ & $8.450,05 €$ & & Recyclable & \begin{tabular}{|ll} 
& Depreciation \\
$(7,18 \%)$ & \\
\end{tabular} & $8.450,05 €$ \\
\hline - R \& D $(7,70 \%)$ & $9.710,55 €$ & & $-60 \%$ & $-\mathrm{R} \& \mathrm{D}(8,25 \%)$ & $9.710,55 €$ \\
\hline - Advertising (5,37\%) & $6.769,37 €$ & \multirow{3}{*}{\multicolumn{2}{|c|}{$\begin{array}{l}\text { Recycled plastic can be purchased } 51 \% \\
\text { cheaper than one-way plastic leading to } \\
\qquad 12.605,04 €(31 \%) \\
\text { lower material cost which now account for } \\
24,33 \% \text { of the total cost. }\end{array}$}} & - Advertising (5,75\%) & $6.769,37 €$ \\
\hline - Warranties $(5,04 \%)$ & $6.349,21 €$ & & & - Warranties $(5,4 \%)$ & $6.349,21 €$ \\
\hline$-\operatorname{Admin}(10,04 \%)$ & $12.651,73 €$ & & & $-\operatorname{Admin}(10,75 \%)$ & $12.651,73 €$ \\
\hline Profit $(7,37 \%)$ & $9.290,38 €$ & \multicolumn{2}{|c|}{$+4.201,68 €$ more Profit } & Profit $(11,47 \%)$ & $13.492,06 €$ \\
\hline
\end{tabular}

Source: (Böhnert, Biewendt, \& Blaschke, 2020). 
The cost of materials is the largest component at $32.7 \%$, which can be further divided into exterior and interior ones. $40 \%$ of the material costs are attributable to the interior, of which $60 \%$ can be replaced by recycled plastics. Further research shows that recycled plastic can be purchased $51 \%$ cheaper than one-way disposable materials. This means that due to green manufacturing, research, and change of materials, the cost of production per minibus can be reduced by $€ 12,605.04$. Following the change in cost, a new calculation has been made, aiming to lower the gross price per minibus to $€ 140,000(6.67 \%)$ in order to increase the overall sales. Given the new net price target of $€ 117,647.06$ instead of $€ 126,050.26$ and material cost savings of $€$ $12,605.04$, the margin has been increased from $€ 9,290.38$ (7.37\%) to $€ 13,492.06$ to $11.47 \%$ per bus.

The Jevons Paradox at $B^{3}$ Engineering Systems

The greening process at $\mathrm{B}^{3}$ Engineering Systems has impacted the environmental factors as well as the production cost and pricing strategy. Part of the saved cost will be used to push sales and demand by reducing the list price. Meanwhile, the overall ecological impact will not exceed the initial figures. Therefore, it is necessary to research the new maximum output and the price elasticity to predict the demand. Table 10 shows how resource consumption is affected by the greening program. The innovations have individually lowered the level of grey energy, $\mathrm{CO}_{2}$ emission, and virtual water consumption. Therefore, each figure must be individually reviewed to describe the maximum number of buses which can be produced without exceeding the initial level of resource consumption.

Table 10. Resource consumption and savings

\begin{tabular}{|c|c|c|}
\hline \multicolumn{3}{|c|}{ Initial Total Consumption (50 Buses) } \\
\hline Grey Energy & CO2 Emission & Virtual Water \\
\hline (50.000 kWh per Bus) & (50t per Bus) & (300.000 I per Bus) \\
\hline $2.500 .000 \mathrm{kWh}$ & 750 t CO2 & $15.000 .000 \mathrm{I}$ \\
\hline \multicolumn{3}{|c|}{ New Total Consumption (50 Buses) } \\
\hline Grey Energy & CO2 Emission & Virtual Water \\
\hline (44.200 kWh per Bus) & (13,2t per Bus) & (271.000 I per Bus) \\
\hline $2.210 .000 \mathrm{kWh}$ & $670 \mathrm{t} \mathrm{CO} 2$ & 13.550 .000 I \\
\hline \multicolumn{3}{|c|}{ Savings } \\
\hline Grey Energy & CO2 Emission & Virtual Water \\
\hline $290.000 \mathrm{kWh}$ & $90 t \mathrm{CO} 2$ & $1.450 .000 \mathrm{I}$ \\
\hline \multicolumn{3}{|c|}{ Possible Production without more Emissions } \\
\hline $2.500 .000 \mathrm{kWh} / 46.200 \mathrm{kWh}$ & $750 \mathrm{t} \mathrm{CO} 2 / 13,5 \mathrm{t}$ CO2 & 15.000 .000 I / $277.200 \mathrm{I}$ \\
\hline$=54,11$ Buses & $=55,55$ Buses & $=54,11$ Buses \\
\hline
\end{tabular}

Source: (Böhnert, Biewendt, \& Blaschke, 2020).

After implementing the greening process, 54 minibuses can be produced without exceeding the resource consumption of the initial production of 50 , which equates to $8 \%$ more output. Second, price elasticity is examined to determine how changes in the asking price will affect the demand. The elasticity equation is shown in Equation 1: Applied formula of demand elasticity:

$E=\frac{\left(\frac{(50-67)}{67} * 100\right)}{\left(\frac{150.000-140.000}{140.000} * 100\right)}=\frac{-25.37 \%}{7.14 \%}=(-3.5532 \%)=3.5532 \%$

If the asking price is lowered by $1 \%$, the total demand will increase by $3.5 \%$. The elasticity and the potential to lower the price by $6.67 \%$ would lead to a demand of 67 minibuses. Table 11 shows the theoretical environmental impact.

Table 11. Environmental impact calculation

\begin{tabular}{|c|c|c|}
\hline \multicolumn{3}{|c|}{ Initial Total Consumption: Output 50 Buses } \\
\hline Grey Energy & CO2 Emission & Virtual Water \\
\hline$(50.000 \mathrm{kWh}$ per Bus $)$ & $(15 \mathrm{t}$ per Bus $)$ & 15.000 .0001 \\
\hline $2.500 .000 \mathrm{kWh}$ & $750 \mathrm{t} \mathrm{CO} 2$ & Virtual Water \\
\hline \multicolumn{2}{|c|}{ Theoretical Total Consumption: Output 67 Buses } \\
\hline Grey Energy & CO2 Emission & $(277.2001$ per Bus $)$ \\
\hline$(46.200 \mathrm{kWh}$ per Bus $)$ & $(13,5 \mathrm{t}$ per Bus $)$ & 18.572 .4001 \\
\hline $3.095 .400 \mathrm{kWh}$ & $904,5 \mathrm{t} \mathrm{CO} 2$ & \\
\hline
\end{tabular}


Table 12 (cont.). Environmental impact calculation

\begin{tabular}{|c|c|c|}
\hline \multicolumn{3}{|c|}{ Theoretical Additional Resource Consumption } \\
\hline $595.400 \mathrm{kWh}$ & $154,5 \mathrm{t} \mathrm{CO} 2$ & 3.572 .400 \\
\hline & New Manufacturing Plan: Output 54 Buses & Virtual Water \\
\hline Grey Energy & CO2 Emission & $(277.2001$ per Bus $)$ \\
\hline$(46.200 \mathrm{kWh}$ per Bus $)$ & $(13,5 \mathrm{t}$ per Bus $)$ & $=14.968 .8001$ \\
\hline$=2.494 .800 \mathrm{kWh}$ & $=729 \mathrm{t}$ CO2 & 31.2001 \\
\hline $5.200 \mathrm{kWh}$ & Saved Resources & $21 \mathrm{t} \mathrm{CO} 2$ \\
\hline
\end{tabular}

Source: (Böhnert, Biewendt, \& Blaschke, 2020).

This new output calculation would lead to the Jevons Paradox. Greener production is implemented, and the environmental impact per bus has decreased, but the savings in manufacturing cost allow for a lower asking price, which would increase the overall demand. This would ultimately lead to the increased overall consumption of resources. At $\mathrm{B}^{3}$ Engineering Systems, the Green Controlling department has decided that the overall resource consumption will not be exceeded. The management agrees, under the condition that revenue must be increased as much as possible. Therefore, the optimal price per bus is calculated, which allows selling 54 buses at the maximum price. By doing so, the maximum revenue is achieved while the Jevons Paradox does not apply. Figure 8 shows the optimal price.

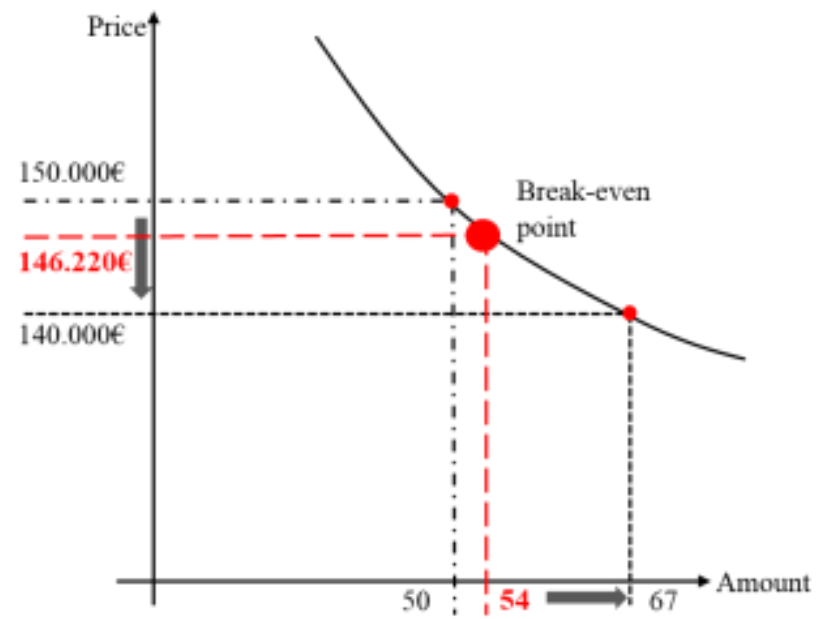

Figure 8. Neutralization of the Jevons Paradox by price adjustment under consideration of the raw resource usage

Source: (York \& Mcgee, Understanding the Jevons paradox, 2016; Jevons (a), 1866).

The adjusted price and output increase the overall revenue of $\mathrm{B}^{3}$ Engineering Systems, which is shown in Table 12.

Table 13. Revenue B ${ }^{3}$ Engineering Systems

\begin{tabular}{|c|c|r|r|}
\hline \multicolumn{4}{|c|}{$\mathrm{B}^{3}$ Engineering Systems-Minibus Standard Model } \\
\hline Manufactory & Output & Price & Revenue \\
\hline Standard & 50 & $150.000,00 €$ & $7.500 .000,00 €$ \\
\hline Green & 54 & $146.220,00 €$ & $7.895 .880,00 €$ \\
\hline
\end{tabular}

Source: (Biewendt, Böhnert, \& Blaschke (b), 2019)

Although the price per bus is lower by $€ 3,780$, the overall revenue increases by 395,880 (5.28\%). By implementing this adjustment, the specifications of the Green Controlling department can be met while satisfying the constraint of the management.

\section{Conclusion}

In fact, the Jevons Paradox does not describe a paradox in its own sense, but only a lack of information for the evaluation and classification of future events. In our example, it is assumed that based on current 
knowledge and logic, the total consumption of resources must decrease, as long as the resource consumption for the manufacture of products is reduced by efficiency gains. In a model without further environmental impacts, this assumption would be correct. However, extending the model to the classic supply-demand function shows that a reduction in resource use correlates with a reduction in production costs. This also directly and indirectly influences the price of the product, which, when it decreases, has an impact on consumer demand.

A reduction in the product price thus increases demand, and thus the supply if the market is not saturated and the supplier has sufficient capacity. Hence, considering the knowledge of environmental influences, an increase in resource consumption as a whole is not paradoxical but a logical consequence of market mechanisms. In the example of $\mathrm{B}^{3}$ Engineering Systems shown here, this effect takes place. The original concept, developed by the Green Controlling subdivision, was to reduce the usage, consumption, and emission of the resource's grey energy, virtual water and $\mathrm{CO}_{2}$. The first step to achieve this was realized through a new product development system of the Green IT sub-division. The resources that have now been freed up were then thus used by the Green Manufacturing subdivision to establish a new production process that also reduces environmental costs and thus the company's overall cost structure. The management has decided to pass on this cost reduction to the customers through a reduced product price.

As a result of the higher production figures due to increased demand, saving resources became absurd from an ecological point of view as overall consumption of resources increased in the first place. Therefore, the authors of this study must confirm zero hypotheses. The use of corporate sustainability results in increased overall output generated and resource consumption of companies through efficiency gains, which precisely describes the Jevons Paradox. Nevertheless, the use case designed by the authors for this paper shows a newly developed concept and perspective on how to neutralize the Jevons paradox while still enabling the company to increase its sales. This approach fits better with a liberal market economy as it is found today in most industrialized countries. In contrast to Jevon's socialist approach, the approach of this paper combines the benefits of efficiency gains through the use of corporate sustainability with the management of total resource consumption through the selling price of the product and consideration of demand elasticity.

\section{Conflict of Interest Statement}

The authors agree that this research was conducted in the absence of any self-benefits, commercial or financial conflicts and declare absence of conflicting interests with the funders.

\section{Acknowledgements}

The Authors want to thank Prof. Dr. Imre Fertő, Prof. Dr. Gergely Tóth, Prof. Dr. Viktória Szente and Prof. Dr. Zoltán Gál for the very helpful and critical questions and remarks during the preparation of this document.

Funding: self-funded.

Author Contributions: conceptualization, Marcel Biewendt; data curation, Arno Böhnert, Florian Blaschke; formal analysis, Marcel Biewendt; funding acquisition, Marcel Biewendt, Arno Böhnert, Florian Blaschke; investigation, Marcel Biewendt; methodology, Arno Böhnert, Florian Blaschke; project administration, Marcel Biewendt; resources, Marcel Biewendt, Arno Böhnert, Florian Blaschke; software, Marcel Biewendt, Arno Böhnert, Florian Blaschke; supervision, Marcel Biewendt, Arno Böhnert, Florian Blaschke; validation, Marcel Biewendt, Arno Böhnert, Florian Blaschke; visualization. Marcel Biewendt, Arno Böhnert, Florian Blaschke; writing - original draft, Marcel Biewendt, Arno Böhnert, Florian Blaschke; writing - review \& editing, Marcel Biewendt, Arno Böhnert, Florian Blaschke.

\section{References}

1. Abduaziz, O., Kie Cheng, J., Mat Tahar, R., \& Varma, R. (2015). A hybrid Simulation model for Green Logistics Assessment in Automotive Industry. (2. D. Automation, Ed.) Procedia Engineering, pp. 960969. doi:10.1016/j.proeng.2015.01.455.

2. Abolhassan, F., \& Kellermann, J. (2016). Effizienz durch Automatisierung: Das "Zero Touch “-Prinzip im IT-Betrieb. Wiesbaden: Gabler Verlag. Available at: https://link.springer.com/book/10.1007\%2F978-3658-10644-7. 
3. Agency, G. F. (2006). Wie private Haushalte die Umwelt nutzen - höherer Energieverbrauch trotz Effizienzsteigerungen. Bundes Umweltamt: Für Mensch und Umwelt. Available at: https://www.umweltbundesamt.de/sites/default/files/medien/publikation/long/3544.pdf.

4. Alcott, B. (2005). Jevons' paradox. Ecological Economics, pp. 9-21. doi:10.1016/j.ecolecon.2005.03.020.

5. Baumgartner, R., \& Ebner, D. (2010, February). Corporate Sustainability Strategies: Sustainability Profiles and Maturity Levels. Sustainable Development, pp. 76-89. doi:10.1002/sd.447.

6. Bhattacharya, A., Jain, R., \& Choudhary, A. (2011). Green Manufacturing: Energy, Products and Processes. Confederation of Indian Industry. The Boston Consulting Group. Available at: chromeextension://ohfgljdgelakfkefopgklcohadegdpjf/https://www.cii.in/webcms/Upload/BCG-

CII\%20Green\%20Mfg\%20Report.pdf.

7. Biewendt, M., Böhnert, A., \& Blaschke (b), F. (2019). Sustainable Revenue Calculation. Hamburg: OwnCalculation. doi: 10.26417/ejes.v6i1.p106-120

8. Brooks, S., Wang, X., \& Sarker, S. (2010). Unpacking Green IT: A Review of the Existing Literature. A Review of Green IT Studies. (A. C. Systems, Ed.) Lima, Peru. Available at: https://aisel.aisnet.org/amcis2010/398/.

9. Brundtland. (2019). Our common future. Report of the 1987 World Commission on Environment and Development. (United-Nations, Ed.) Oslo. Available at: https://sswm.info/sites/default/files/reference attachments/UN WCED 1987 Brundtland Report.pdf.

10. Camilleri, M. (2013, October 31). Advancing the Sustainable Tourism Agenda Through Strategic CSR Perspectives. Tourism Planning and Development. doi:10.1080/21568316.2013.839470.

11. Camilleri, M. (2017). Corporate Sustainability and Responsibility. Malta: Springer. doi:10.1186/s41180017-0016-5.

12. Chan, D. S. (2003, March 03). Simulation modelling in virtual manufacturing analysis for integrated product and process design. Assembly Automation 23. doi:10.1108/01445150310460114.

13. Deif, A. (2011, September). A system model for green manufacturing. Journal of Cleaner Production, pp. 1553-1559. doi:10.1016/j.jclepro.2011.05.022.

14. Dornfeld, D., Yuan, C., Diaz, N., Zhang, T., \& Vijayaraghavan, A. (2013). Introduction to Green Manufacturing. Green Manufacturing, pp. 1-290. doi:10.1007/978-1-4419-6016-0 1.

15. Dyllick, T., \& Hockerts, K. (2002). Beyond the business case for corporate sustainability. (L. a. John Wiley \& Sons, Ed.) Business Strategy and the Environment, 11(2). doi:10.1002/bse.323.

16. Eigner, M., \& Stelzer, R. (2009). Product Lifecycle Management (Vols. 2., neu bearbeitete Auflage). Berlin Heidelberg: Springer-Verlag. doi:10.1007/978-3-540-68401-5.

17. Elliot, S. (2007). Environmentally Sustainable ICT: A Critical Topic for IS Research? (P. A. Systems, Ed.) Available at: http://aisel.aisnet.org/pacis2007/114.

18. Erek, K., Loeser, F., Schmidt, N.-H., \& Zarnekow, R. (2011). Green It Strategies: A Case Study-Based Framework For Aligning Green It With Competitive Environmental Strategies. PACIS 2011 Proceedings. 59. Available at: http://aisel.aisnet.org/pacis2011/59.

19. Etzion, D. (2007, August 1). Research on Organizations and the Natural Environment, 1992-Present: A Review. Journal of Management, no. 4 637-664, pp. 637-664. doi:10.1177/0149206307302553.

20. Feng, W.-c., \& Cameron, K. (2007, December). The green500 list: Encouraging sustainable supercomputing. Computer. doi:10.1109/MC.2007.445.

21. Friedag, H. R. (2019, February 11). ControllingWiki. Available at: https://www.controllingwiki.com/de/index.php/Green Controlling.

22. Friedman, M., Foley, \& Marrewijk, M. v. (2003). Concepts and Definitions of CSR and Corporate Sustainability: Between Agency and Communion. Journal of Business Ethics 44, pp. 95-105. doi:10.1023/A:1023331212247.

23. German-Federal-Statistical-Office. (2019). DESATIS: Statistisches Bundesamt. Available at: https://www.destatis.de.

24. Global Reporting Initiative. (2019). Homepage: Global Reporting Initiative. Amsterdam, Netherlands. Available at: https://www.globalreporting.org/Pages/default.aspx.

25. Hahn, T., \& Scheermesser, M. (2005). Approaches to Corporate Sustainability among German Companies. Corporate Social Responsibility and Environmental Management, pp. 150-165. doi: $10.1002 / \mathrm{csr} .100$.

26. Haufe. (2019, February 11). Haufe. Available at: https://www.haufe.de/thema/green-controlling/. 
27. Hopkins, M. (2004, May 1). Corporate social responsibility: an issues paper. (I. L. Organization, Ed.) SSRN Electronic Journal, No. 27, pp. 1-41. doi:10.2139/ssrn.908181.

28. International Controller Verein eV. (2011). Green Controlling - eine (neue) Herausforderung für den Controller. Stutgart: Internationaler Controller Verein eV Ideenwerkstatt. Available at: chromeextension://ohfgljdgelakfkefopgklcohadegdpjf/https://www.icvcontrolling.com/fileadmin/Assets/Content/AK/Green\%20Controlling/ICV11_Studienbericht_Green_Co ntrolling_final.pdf.

29. Jevons (a), W. S. (1866). The Coal Question: An Inquiry Concerning the Progress of the Nation, and the Probable Exhaustion of Our Coal Mines. London \& Cambridge: Macmillan \& Co. Available at: https://oll.libertyfund.org/titles/jevons-the-coal-question.

30. Jevons (b), W. S., \& Flux, A. W. (1965). The coal question; an inquiry concerning the progress of the Nation, and the probable exhaustion of our coal-mines. London and Cambridge: New York, A. M. Kelley. Available at: https://www.sciencedirect.com/science/article/pii/S1877042813002929\#bbib0210.

31. Lewis, W. A. (2003). Theory of Economic Growth. London: Routledge. Available at: https://doi.org/10.4324/9780203709665.

32. Lillywhite, R. D. (2010). Footprinting methods for assessment of the environmental impacts of food production and processing. In U. Sonesson, J. Berlin, \& F. Ziegler, Environmental Assessment and Management in the Food Industry (pp. 255 - 271). Woodhead Publishing. Available at: http://wrap.warwick.ac.uk/42771/.

33. Marrewijk, M. v., \& Werre, M. (2003, May). Multiple Levels of Corporate Sustainability. Journal of Business Ethics, pp. 107-119. doi:10.1023/A:1023383229086.

34. Molla, A., Cooper, V. A., \& Pittayachawan, S. (2009). IT and Eco-sustainability: Developing and Validating a Green IT Readiness Model. In I. C. Systems (Ed.), ICIS 2009 Proceedings, Paper 141. Available at: http://aisel.aisnet.org/icis2009/141.

35. Montiel, I., \& Delgado-Ceballos, J. (2014, April). Defining and Measuring Corporate Sustainability: Are We There Yet? Journal of Organization \& Environment, 27(2). doi:10.1177/1086026614526413.

36. Murugesan, S. (2008). Harnessing Green IT: Principles and Practices. Adopting a holistic approach to greening IT is our responsibility toward creating a more sustaining environment(10(1):24 - 33). (I. Xplore, Ed.) IT Professional . doi:10.1109/MITP.

37. Nations, U. (1987). Report of the World Commission on Environment and Development: Our Common Future. New York City, New York: UN. Available at: http://www.environmentandsociety.org/mml/unworld-commission-environment-and-development-ed-report-world-commission-environment-and.

38. Pao, H.-T., \& Tsai, C.-M. (2011, March). Modeling and forecasting the CO2 emissions, energy consumption, and economic growth in Brazil. Energy, pp. 2450-2458. doi:10.1016/j.energy.2012.01.037.

39. Pao, H.-T., Fu, H.-C., \& Tseng, C.-L. (2012, February). Energy, pp. 400-409. doi:10.1016/j.energy.2011.01.032.

40. Polimeni, J., \& Iorgulescu, R. (2006, December 1). Jevons' Paradox and the myth of technological liberation. Ecological Complexity 3, pp. 344-353. doi:10.1016/j.ecocom.2007.02.008.

41. Rehman, M. A., \& Shrivastava, R. (2013, January 1). Green manufacturing (GM): past, present and future (a state of art review). World Review of Science Technology and Sustainable Development, pp. 17-55. doi:10.1504/WRSTSD.2013.050784.

42. Saunders, M., Lewis, P., \& Thornhill, A. (2009). Research Methods for Business Students: 5th Edition. Edinburgh: Pearson Professional Limited. Available at: chromeextension://ohfgljdgelakfkefopgklcohadegdpjf/https://eclass.teicrete.gr/modules/document/file.php/DLH 105/Research\%20Methods\%20for\%20Business\%20Students\%2C\%205th\%20Edition.pdf.

43. Sayeed, L., \& Gill, S. (2009). Implementation of Green IT: Implications for a Dynamic Resource. In A. C. Systems (Ed.). (pp. 1-9). San Fransico: Americas Conference on Information Systems. Available at: http://aisel.aisnet.org/amcis2009/381.

44. Schaltegger, S., Lüdeke-Freund, F., \& Hansen, E. (2012, July 1). Business cases for sustainability: the role of business model innovation for corporate sustainability. International Journal of Innovation and Sustainable Development, 6, 95-119. doi:10.1504/IJISD.2012.046944.

45. Schmermbeck, H. (2019, January 8). On Making a Difference: Towards an Integrative Framework for Green IT and Green IS Adoption. (I. C. Sciences, Ed.) Hawaii International Conference on System Sciences 2019, pp. 1-10. doi:10.24251/HICSS.2019.248. 
46. Schrader, C., \& Vollmar, B. H. (2013, April). Green Controlling: ein wesentlicher Schritt auf dem Weg zur nachhaltig orientierten Unternehmensführung. ZE Zentrum für Entrepreneurship. Göttingen: PFH Private University of Applied Sciences. Available at: https://www.pfh.de/fileadmin/Content/PDF/forschungspapiere/green controlling ein wesentlicher_schr itt auf dem weg zur nachhaltig orientierten unternehmensfuehrung schrader Vollmar fp 201304 .pdf.

47. Schrave, J. (2003, May). Multiple Levels of Corporate Sustainability. Journal of Business Ethics, pp. 107119. doi:10.1023/A\%3A1023383229086.

48. Scopus. (2019a). Corporate sustainability: Journal and conference paper. Amsterdam, Netherlands. Available at: https://sus.cirmcs.e.corpintra.net/results/results.uri?numberOfFields $=0 \& s r c=s \& c l i c k e d L i n k=\& e d i t=\& e d i t S a v e S e a r c h$ $=$ \&origin $=$ searchbasic\&authorTab $=\&$ affiliation $\mathrm{Tab}=\&$ advancedTab $=\&$ scint $=1 \&$ menu=search\&tablin $=$ \&searchterm1=Corporate+sustainability \&field1=TITLE\&date.

49. Scopus. (2019b). Green IT: Journal and conference paper. (Elsevier, Ed.) Amsterdam, Netherlands. Available at:

https://sus.cirmcs.e.corpintra.net/results/results.uri?numberOfFields $=0 \&$ src $=$ s \&clickedLink=\&edit=\&editSaveSearch $=\&$ origin $=$ searchbasic\&author $\mathrm{Tab}=\&$ affiliation $\mathrm{Tab}=\& \mathrm{advancedTab}=\&$ scint $=1 \&$ menu $=$ search \&tablin $=$ \&searchterm $1=$ Green+IT\& field1=TITLE\&dateType $=$ Publication .

50. Scopus. (2019c). Sustainability Controlling: Journal and conference paper. (Elsevier, Ed.) Amsterdam, Netherlands. Available at: https://sus.cir-mcs.e.corpintra.net/results/results.uri?sort=plf$\mathrm{f} \& \mathrm{src}=\mathrm{s} \& \mathrm{st} 1=$ Sustainability + Controlling \&st $2=$ Controlling \&sid=4e8bfa53cb15fe29d3e55b9ac76fb689 \&sot=b\&sdt=b\&sl=33\&s=TITLE\% 28Sustainability + Controlling\%29\&origin=searchhistory \&txGid=38 36fe2adf911.

51. Scopus. (2019d). Sustainable Controlling: Journal and conference paper. Amsterdam, Netherlands. Available at:

https://sus.cirmcs.e.corpintra.net/results/results.uri?numberOfFields $=0 \&$ src $=$ s\&clickedLink=\&edit=\&editSaveSearch $=$ \&origin $=$ searchbasic \&authorTa $=\&$ affiliation $T a b=\&$ advancedTab $=\&$ scint $=1 \&$ menu $=$ search \&tablin $=$ \&searchterm1=Sustainable+Controlling\&field1=TITLE\&dateT .

52. Scopus. (2019e). Green Manufacturing: Journal and conference paper. (Elsevier, Ed.) Amsterdam, Netherlands. Available at: https://sus.cirmcs.e.corpintra.net/results/results.uri?numberOfFields $=0 \& s r c=s \& c l i c k e d L i n k=\& e d i t=\& e d i t S a v e S e a r c h$ $=$ \&origin $=$ searchbasic \&authorTab $=\&$ affiliation $T a b=\& a d v a n c e d T a b=\&$ scint $=1 \&$ menu $=$ search \&tablin $=$ \&searchterm1=Green+Manufacturing \& field1=TITLE\&dateType $=$.

53. Singh, H., Boland, M., \& Thompson, A. (2014, July 25). Milk Proteins: The Future. (A. Press, Ed.) Food Science and Technology, pp. 571 - 583. doi:10.1016/B978-0-12-405171-3.00021-0.

54. Sri Darapu, S., \& Satish Kumar Darapu, S. (2014, December 21). Green Manufacturing Technologies A Review. (M. o. Development, Ed.) Indian Engineering Congress, pp. 1-8. doi:10.13140/RG.2.1.3257.1126.

55. Staff, C. \&. (2019, March). Sustainability Survey. (M. Biewendt, Interviewer) Hamburg. Available at:

56. Statista. (2019, May 10). Statista. Available at: https://de.statista.com/statistik/daten/studie/239764/umfrage/weltweiter-stromverbrauch/.

57. Swarnapali, N. (2017, January). Corporate sustainability: A Literature review. Rajarata University of Sri Lanka, Department of Accountancy \& Finance Faculty of Management Studies. Sri Lanka: Journal for Accounting Researchers and Educators, l(1). Available at: https://www.researchgate.net/publication/317428267_Corporate_sustainability_A_Literature_review.

58. Tonelli, F., Taticchi, P., \& Evans, S. (2013, January 1). Industrial sustainability: challenges, perspectives, actions. (I. J. Research, Ed.) International Journal of Business Innovation and Research, Vol. 7, p. 1751. doi:10.1504/IJBIR.2013.052576.

59. Topalli, N., \& Buluş, A. (2011, July). Energy Efficiency and Rebound Effect: Does Energy Efficiency Save Energy? Energy and Power Engineering Vol 3 No 3. doi:10.4236/epe.2011.33045.

60. Tschandl, M., \& Posch, A. (2003). Integriertes Umweltcontrolling. Wiesbaden: Gabler Verlag. Available at: https://www.springer.com/de/book/9783834930316.

61. UN Global Compact. (2019). Homepage: UN Global Compact. New York, United States of America. Available at: https://www.unglobalcompact.org/. 
62. Verma, D., Dixit, R., \& Singh, K. (2018, March 1). Green Supply Chain Management: A Necessity for Sustainable Development. Journal of Supply Chain Management Vol 15, pp. 40-58. doi:10.5772/intechopen.87158.

63. Vlek, C., \& Steg, L. (2007, February 1). Human Behavior and Environmental Sustainability: Problems, Driving Forces, and Research Topics. Journal of Social Issues, pp. 1-19. doi:10.1111/j.15404560.2007.00493.x.

64. Westkämper, E., Spath, D., Constantinescu, C., \& Lentes, J. (2013). Digitale Produktion. Berlin Heidelberg: Springer-Verlag. doi:10.1007/978-3-642-20259-9.

65. York, R. (2006, December 1). Ecological paradoxes: William Stanley Jevons and the paperless office. Human Ecology Review, pp. 143-147. Available at: https://www.semanticscholar.org/paper/EcologicalParadoxes\%3A-William-Stanley-Jevons-and-York/36f11cf7c893b8b346bb5ce08751a6440f421af4.

66. York, R., \& Mcgee, J. A. (2016, January 2). Understanding the Jevons paradox. Environmental Sociology 2(1), 77-87. doi:10.1080/23251042.2015.1106060. 